\title{
Utilization of Information Technology to Increase Human Resources Capacity and Internal Control Systems on Local Government Financial Reporting Information
}

\author{
Marsyanda Eka Pratiwi", Muhammad Din, Rahma Masdar, Andi Mattulada Amir, Femilia Zahra, \\ Abdul Kahar, Lucyani Meldawati
}

Department of Accounting, Faculty of Economics and Business, Tadulako University, Palu, Indonesia

Received September 24, 2021; Revised November 25, 2021; Accepted December 23, 2021

\begin{abstract}
Cite This Paper in the following Citation Styles
(a): [1] Marsyanda Eka Pratiwi, Muhammad Din, Rahma Masdar, Andi Mattulada Amir, Femilia Zahra, Abdul Kahar, Lucyani Meldawati, "Utilization of Information Technology to Increase Human Resources Capacity and Internal Control Systems on Local Government Financial Reporting Information," Universal Journal of Accounting and Finance, Vol. 10, No. 1, pp. 191-199, 2022. DOI: 10.13189/ujaf.2022.100120.
\end{abstract}

(b): Marsyanda Eka Pratiwi, Muhammad Din, Rahma Masdar, Andi Mattulada Amir, Femilia Zahra, Abdul Kahar, Lucyani Meldawati (2022). Utilization of Information Technology to Increase Human Resources Capacity and Internal Control Systems on Local Government Financial Reporting Information. Universal Journal of Accounting and Finance, 10(1), 191-199. DOI: 10.13189/ujaf.2022.100120.

Copyright $\bigcirc 2022$ by authors, all rights reserved. Authors agree that this article remains permanently open access under the terms of the Creative Commons Attribution License 4.0 International License

\begin{abstract}
There are increasing demands from the public related to the accountability and transparency in public sector administration. The governments usually respond by providing financial information to the public. In order to fulfill public rights to the information, government is also establishing the efficient way to achieve transparency by utilizing information technology (IT) in both financial management and public administration. This study aims to analyze the effect of human resource capacity and government internal control systems on the value of local government financial reporting information using information technology as a moderating variable. The population in this study is the financial manager in 41 government units in Palu City, Indonesia. The sampling technique uses purposive sampling with analysis tools processing data using WarpPLS. The results showed that human resource capacity had a positive and significant effect on the value of local government financial reporting information. The results also revealed that government's internal control system had a positive and significant effect on the value of local government financial reporting information. In terms of moderating effects, the results found that the use of information technology moderates the
\end{abstract}

relationship between human resource capacity and the value of local government financial reporting information and the relationship of the government's internal control system to the value of local government financial reporting information.

Keywords Human Resource Capacity, Value of Financial Reporting Information, Government Internal Control System, Information Technology

\section{Introduction}

There are increasing demands for the implementation of public accountability by public sector organizations in development of the public sector in Indonesia [1]. This demand for accountability is related to the need for transparency and accountability in providing information to the public in order to fulfill public rights $[2,3]$. One of the information needed by the public is information on regional financial management in the form of financial reports. Therefore, the information presented in financial 
statements must be useful for stakeholders, both users and auditors of financial statements [4].

Information will be useful if the financial statements have value [5]. Information that has value will produce quality financial reports. Government Regulation No. 71 of 2010 concerning Government Accounting Standards has four qualitative characteristics in assessing the quality of a financial report, among them are relevant, reliable, comparable, and understandable. Indonesian Supreme Auditor (BPK) found a number of problems and weaknesses in the regional government financial statement (LKPD) for the 2018 fiscal year. Problems include the inadequate management or administration of fixed assets or regional owned goods that occurred in nine regions in Central Sulawesi regencies [6]. In the 2018 fiscal year, BPK found problems that occurred in the Palu city government, namely the management of supplies was not orderly and the acquisition of disaster assistance had not been assessed and reports on the use of the regional budget for expenditure on life insurance for disaster victims were not supported by complete and legal documents [6].

The value of local government financial reporting information can be seen based on several factors that can influence the first thing is the capacity of human resources, with research results stating that human resource capacity affects the value of local government financial reporting information [7], [8], [9], [10] (Hertati et al., 2019; Afiah \& Rahmatika, 2014; Das, 2013; Vithana et al., 2021). The second thing is the government's internal control system. The results of the study state that the government's internal control system affects the value of local government financial reporting information [11], [12], [13], [14], [15].

Another factor that also affects the value of financial reporting information is the use of information technology [16], [17], [18], [19], [20]. Human resource capacity and the government's internal control system can be more effective if supported by utilizing existing information technology. Utilization of information technology that offers speed in processing transaction data and storing large amounts of data reports is expected to help produce the value of quality financial reporting information. Palu City was able to maintain an unqualified opinion from the BPK, but in the last year, namely the 2018 fiscal year, the Palu City government financial report still found problems and weaknesses including the government's internal control system. This needs to be considered because the lack of human resource development and the government's internal control system as well as the less than use of information technology results in the underperformance of government units, so that it affects the value of local government financial reporting information.

\section{Literature Review and Hypotheses Development}

\subsection{Human Resource Capacity and Financial Reporting Information}

One of the improvement steps that need to be taken to realize more optimal regional financial management is to increase the capacity of human resources. This is because one of the things that determine the quality of financial statement is basically related to HR problems as the manager [21], [22]. Therefore, local governments need quality human resources to produce valuable information. Previous research on the effect of human resource capacity on the value of local government financial reporting information has been carried out. [7], [8], [9], [10] showing that human resource capacity has a positive and significant effect on the value of local government financial reporting information. Based on the explanation, the first hypothesis in this study is as follows:

H1: Human Resource Capacity has a positive effect on Financial Reporting Information.

\subsection{Internal Control System and Financial Reporting Information}

The government's internal control system is expected to be able to prevent and provide protection for organizational data by implementing the five elements of internal control system. Government Regulation No. 60 of 2008 specified the control environment, risk control, control activities, information and communication [23]. It also regulated internal control monitoring effectively and efficiently. The ultimate goals are to avoid fraud and the risk of wrong procedures and maintain the reliability of financial reporting and to produce the value of timely financial reporting information [24]. Previous research on the effect of the government's internal control system on the value of local government financial reporting information has been carried out with the results of research that the government's internal control system affects the value of local government financial reporting information [11], [12], [13], [14], [15], [25]. Based on the explanation above, the second hypothesis in this study is as follows:

H2: There is a positive effect of Internal Control System on Financial Reporting Information.

\subsection{Human Resource Capacity, Financial Reporting Information and Information Technology}

Timely information can be generated with the role of technology. The use of information technology can help human resources in carrying out their duties and responsibilities easily and does not require a long time. Information technology has had a positive impact by 
streamlining financial reporting times and avoiding human errors in the financial reporting process so that financial reporting becomes efficient and timely [26] (Fakhimuddin et al., 2021). Therefore, it is hoped that the government can increase the use of information technology so that the performance of human resources also increases and can have an impact on the value of local government financial reporting information. Previous research on the effect of human resource capacity on the value of local government financial reporting information moderated by the use of information technology was conducted by some studies [16], [17], [18], [19], [20] which stated that the use of information technology moderated the effect of human resource capacity on the value of local government financial reporting information. Based on the explanation, the third hypothesis is as follows:

H3: Utilization of information technology moderates the relationship between human resource capacity and financial reporting information.

\subsection{Internal Control System, Financial Reporting Information and Information Technology}

Utilization of information technology and government internal control systems is expected to contribute to each other to prevent and detect errors in the accounting process by providing protection for organizational data from the threat of fraud or system sabotage. Internal control systems role in maintaining the reliability of financial statements is supported by the use of information technology to minimize the occurrence of errors in calculations and recording of financial transactions, thereby fulfilling the principle of order by submitting financial reports in a timely manner [27], [28]. Previous research on the effect of the government's internal control system on the value of local government financial reporting information moderated by the use of information technology was conducted stated that the use of information technology moderated the effect of the government's internal control system on the value of local government financial reporting information [16], [17], [18], [19], [20]. Based on the explanation, the fourth hypothesis is as follows:

H4: Information technology strengthens the positive effect of internal control system on financial reporting information.

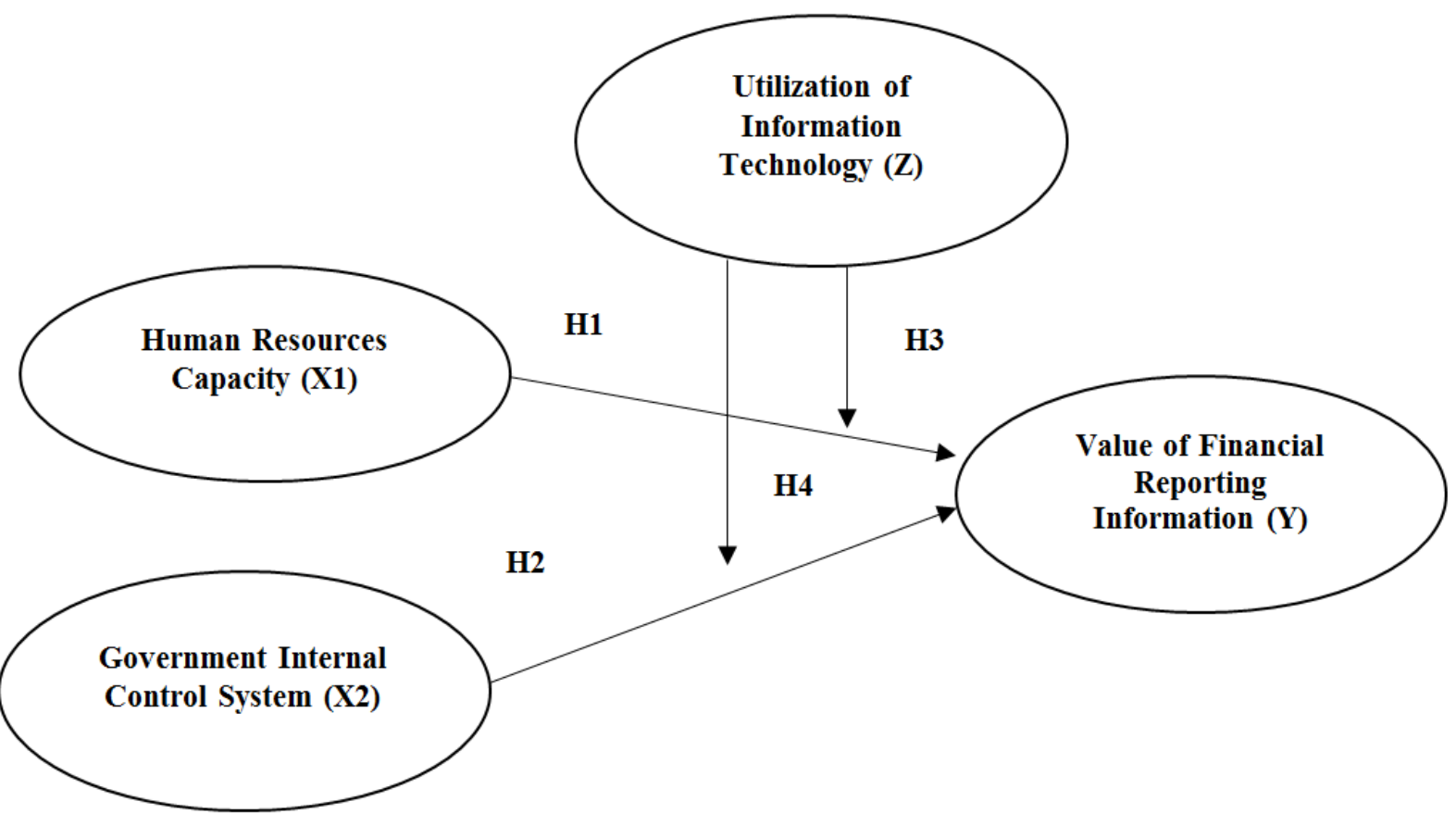

Figure 1. Research Framework 


\section{Research Methods}

The object of this research is human resource capacity (X1) government internal control system (X2), value of local government financial reporting information $(\mathrm{Y})$ and Information technology utilization ( $\mathrm{Z}$ ), studied in 41 Regional Apparatus Organizations of Palu City. The type of research used is survey research, which uses a sample size of a population and uses a questionnaire as a data collection tool.

The type of data used is quantitative data. Sources of data used are obtained from primary data and secondary data. The population in this research is the head of government units, secretary, head of sub-division of finance and treasurer with purposive sampling.

In this study, the data was processed using WarpPLS Version 0.7. The stages of data analysis in PLS are [29] by developing a specification model, namely the path analysis model, including test the Measurement Model (Outer model) which is used to test the validity and test the reliability, structural Model Test (Inner model) to assess the effect of one variable on other variables, and weight estimation where the case value of the latent variable can be estimated. It is also done by evaluating the measurement model, structural models, and hypothesis testing.

\section{Results}

Table 1 showed that the composite reliability value and Cronbach's alpha value for all constructs $>0.70$. Thus, it can be said that the reliability requirements of this research instrument have been met.

Table 1. Reliability Test Results

\begin{tabular}{|c|c|c|c|}
\hline Variable & $\begin{array}{c}\text { Composite } \\
\text { Reliability }\end{array}$ & $\begin{array}{c}\text { Cronbach's } \\
\text { Alpha }\end{array}$ & Information \\
\hline $\begin{array}{c}\text { Human } \\
\text { Resources } \\
\text { Capacity }\end{array}$ & 0.889 & 0.853 & Reliable \\
\hline $\begin{array}{c}\text { Government } \\
\text { Internal Control } \\
\text { System }\end{array}$ & 0.928 & 0.917 & Reliable \\
\hline $\begin{array}{c}\text { Value of } \\
\text { Financial } \\
\text { Reporting } \\
\text { Information }\end{array}$ & 0.921 & 0.904 & Reliable \\
\hline $\begin{array}{c}\text { Utilization of } \\
\text { Information } \\
\text { Technology }\end{array}$ & 0.899 & 0.871 & Reliable \\
\hline
\end{tabular}

Moreover, the validity of the instrument is seen from the value of convergent validity and discriminant validity. To evaluate convergent validity, it is done by looking at the results of the loading values presented in Table 2 .

Table 2. Loading Factor

\begin{tabular}{|c|c|c|c|}
\hline Items & Loading Factor & Items & $\begin{array}{c}\text { Loading } \\
\text { Factor }\end{array}$ \\
\hline HR1 & 0.668 & Continued... & - \\
\hline HR2 & 0.725 & IT6 & 0.760 \\
\hline HR3 & 0.818 & IT7 & 0.693 \\
\hline HR4 & 0.636 & IT8 & 0.685 \\
\hline HR5 & 0.669 & IC1 & 0.638 \\
\hline HR6 & 0.718 & IC2 & 0.592 \\
\hline HR7 & 0.864 & IC3 & 0.657 \\
\hline FR1 & 0.752 & IC4 & 0.309 \\
\hline FR2 & 0.714 & IC5 & 0.521 \\
\hline FR3 & 0.764 & IC6 & 0.741 \\
\hline FR4 & 0.700 & IC7 & 0.683 \\
\hline FR5 & 0.677 & IC 8 & 0.762 \\
\hline FR6 & 0.675 & IC9 & 0.641 \\
\hline FR7 & 0.809 & IC10 & 0.758 \\
\hline FR8 & 0.788 & IC11 & 0.786 \\
\hline FR9 & 0.706 & $\mathrm{IC} 12$ & 0.585 \\
\hline FR10 & 0.740 & $\mathrm{IC} 13$ & 0.510 \\
\hline IT1 & 0.662 & IC14 & 0.700 \\
\hline IT2 & 0.651 & $\mathrm{IC} 15$ & 0.638 \\
\hline IT3 & 0.723 & IC16 & 0.670 \\
\hline IT4 & 0.818 & IC17 & 0.641 \\
\hline IT5 & 0.800 & IC18 & 0.741 \\
\hline
\end{tabular}

Table 2 showed that there are 5 indicators whose values are < 0.60, namely: X2.2 (0.592); X2.4 (0.309); X2.5 $(0.521) ; \mathrm{X} 2.12(0.585)$ and X2.13 (0.510). In addition to looking at the cross-loading value to test the validity, a convergent validity test was carried out by looking at the results of the average variances extracted (AVE) value with a value $>0.50$. The AVE values are presented in Table 3.

Table 3. AVE value

\begin{tabular}{|c|l|}
\hline Variable & AVE \\
\hline Human Resources Capacity (HR) & 0.537 \\
\hline Internal Control System (IC) & 0.426 \\
\hline Value of Financial Reporting Information (FR) & 0.539 \\
\hline Utilization of Information Technology (IT) & 0.528 \\
\hline
\end{tabular}

Table 3 showed that the AVE value on the government internal control system variable does not meet the requirements and the discriminant validity value is presented in Table 4. 
Table 4. Discriminant Validity

\begin{tabular}{|c|c|c|c|c|c|c|}
\hline & HR & IC & FR & IT & IT*HR & IT*IC \\
\hline HR & 0.733 & 0.648 & 0.725 & 0.579 & 0.234 & 0.355 \\
\hline IC & 0.648 & 0.653 & 0.688 & 0.488 & 0.407 & 0.511 \\
\hline FR & 0.725 & 0.688 & 0.734 & 0.651 & 0.388 & 0.363 \\
\hline IT & 0.579 & 0.488 & 0.651 & 0.726 & 0.148 & 0.169 \\
\hline IT*HR & 0.234 & 0.407 & 0.388 & 0.148 & 1.000 & 0.722 \\
\hline IT*IC & 0.355 & 0.511 & 0.363 & 0.169 & 0.722 & 1.000 \\
\hline
\end{tabular}

Table 5. Loading Value (After Dispose of 5 Indicators)

\begin{tabular}{|c|c|c|c|c|c|}
\hline Items & Loading Value & Information & Items & Loading Value & Information \\
\hline HR1 & 0.668 & Valid & Continued... & - & Valid \\
\hline HR2 & 0.725 & Valid & IT6 & 0.760 & Valid \\
\hline HR3 & 0.818 & Valid & IT7 & 0.693 & Valid \\
\hline HR4 & 0.636 & Valid & IT8 & 0.685 & Valid \\
\hline HR5 & 0.669 & Valid & IC1 & 0.603 & Valid \\
\hline HR6 & 0.718 & Valid & IC2 & 0.619 & Valid \\
\hline HR7 & 0.864 & Valid & IC3 & 0.762 & Valid \\
\hline FR1 & 0.752 & Valid & IC4 & 0.685 & Valid \\
\hline FR2 & 0.714 & Valid & IC5 & 0.800 & Valid \\
\hline FR3 & 0.764 & Valid & IC6 & 0.672 & Valid \\
\hline FR4 & 0.700 & Valid & IC7 & 0.770 & Valid \\
\hline FR5 & 0.677 & Valid & IC8 & 0.792 & Valid \\
\hline FR6 & 0.675 & Valid & IC9 & 0.693 & Valid \\
\hline FR7 & 0.809 & Valid & IC10 & 0.656 & Valid \\
\hline FR8 & 0.788 & Valid & IC11 & 0.686 & Valid \\
\hline FR9 & 0.706 & Valid & $\mathrm{IC} 12$ & 0.672 & Valid \\
\hline FR10 & 0.740 & Valid & $\mathrm{IC} 13$ & 0.762 & Valid \\
\hline IT1 & 0.662 & Valid & $\mathrm{IC} 14$ & 0.603 & Valid \\
\hline IT2 & 0.651 & Valid & IC15 & 0.619 & Valid \\
\hline IT3 & 0.723 & Valid & IC16 & 0.762 & Valid \\
\hline IT4 & 0.818 & Valid & IC17 & 0.685 & Valid \\
\hline IT5 & 0.800 & Valid & IC18 & 0.800 & Valid \\
\hline
\end{tabular}

Table 6. AVE Value (After Clear 5 Indicators)

\begin{tabular}{|c|c|}
\hline Variable & AVE \\
\hline Human Resources Capacity & 0.537 \\
\hline Government Internal Control System & 0.502 \\
\hline Value of Financial Reporting Information & 0.539 \\
\hline Utilization of Information Technology & 0.528 \\
\hline
\end{tabular}

To increase the AVE value, indicators that have a loading value below 0.60 are removed from the model (Latan \& Ghozali, 2016). Based on Table 4, there are 5 indicators being removed from the model whose values were below 0.60, namely: IC2 (0.592); IC4 (0.309); IC5
(0.521); IC12 (0.585) and IC13 (0.510).

The deletion of these 5 indicators resulted in all variables having an AVE value of more than 0.50. These results indicate that the research instruments have met convergent validity (Table 6). 
Table 7. Discriminant Validity (After Remove 5 Indicators)

\begin{tabular}{|c|c|c|c|c|c|c|}
\hline & HR & IC & FR & IT & IT*HR & IT*IC \\
\hline HR & $\mathbf{0 . 7 3 3}$ & 0.600 & 0.725 & 0.579 & 0.234 & 0.342 \\
\hline IC & 0.600 & $\mathbf{0 . 7 0 8}$ & 0.667 & 0.428 & 0.400 & 0.519 \\
\hline FR & 0.725 & 0.667 & $\mathbf{0 . 7 3 4}$ & 0.651 & 0.388 & 0.334 \\
\hline IT & 0.579 & 0.428 & 0.651 & $\mathbf{0 . 7 2 6}$ & 0.148 & 0.133 \\
\hline IT*HR & 0.234 & 0.400 & 0.388 & 0.148 & $\mathbf{1 . 0 0 0}$ & 0.689 \\
\hline IT*IC & 0.342 & 0.519 & 0.334 & 0.133 & 0.689 & $\mathbf{1 . 0 0 0}$ \\
\hline
\end{tabular}

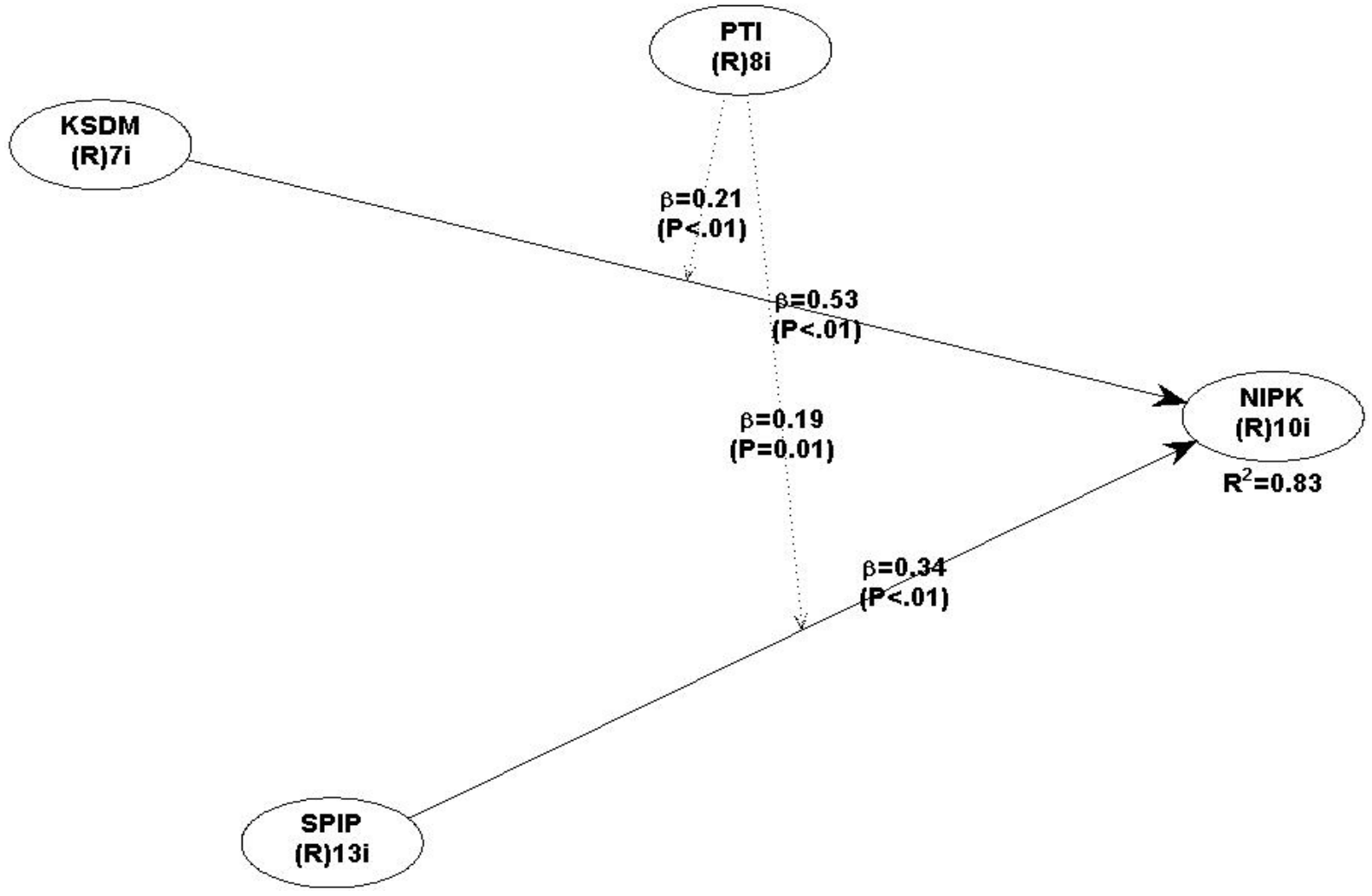

Figure 2. Full Model Path

Table 7 showed the value of the square root of average variance extracted after removing 5 indicators is obtained, which is greater than the correlation value between the constructs and other constructs, meaning that the discriminant validity value of the instrument in this study is fulfilled.

The figure produces a significance level $>0.05$, which can be said that all paths in the research model are significant (Figure 2).

Table 8. R-Square, Adj R-Squared and Q-Squared values

\begin{tabular}{|c|c|}
\hline Items & FR \\
\hline$R$-Square & 0.827 \\
\hline Adj $R$-Square & 0.821 \\
\hline$Q$ Squared & 0.675 \\
\hline
\end{tabular}

Table 8 showed R-squared value for the variable value of financial reporting information of 0.827 is included in the high category $(<0.35)$. This value means that the variable of human resource capacity (HR), government internal control system (IC) and moderation of the use of information technology (IT) is able to influence the variable value of financial reporting information (FR) by $82.7 \%$, while the remaining $17.3 \%$ is influenced by other variables. The results of data processing found that the predictive validity value of this research model was good. This is because the Q-Squared value of the financial reporting information value variable is 0.675 , the value is above zero.

Table 9. Effect Size for Path Coefficient Value

\begin{tabular}{|c|c|c|c|c|}
\hline Relationship & HR & IC & IT*HR & IT*IC \\
\hline FR & 0.400 & 0.235 & 0.115 & 0.078 \\
\hline
\end{tabular}

Table 9 showed the effect size value used to measure how strong the predictor variables affect the criteria can 
be explained as follows: First, the magnitude of the influence of human resource capacity on the value of financial reporting information is 0.400 . This value indicates that the involvement of human resources in the government environment in the preparation of financial reports in the related units has a role of $40 \%$. This value is included in the strong category. Second, the magnitude of the influence of the government's internal control system on the value of financial reporting information is 0.235 . This value indicates that the involvement of the government's internal control system in the government environment in the preparation of financial reports in the related units has a role of $23.5 \%$, and this value is in the medium category. Third, the moderating role of the use of information technology on the relationship between human resource capacity and the value of financial reporting information is 0.115 . This value explains that the involvement of human resources is strengthened by information technology in the preparation of financial reports in the related units has a role of $11.5 \%$. This value is in the medium category. Fourth, the moderating role of the use of information technology on the relationship between the government's internal control system and the value of financial reporting information is 0.078 . This value explains that the involvement of the government's internal control system is strengthened by information technology in the preparation of financial statements in the related units, which has a role of $7.8 \%$, the value is in the medium category.

Based on Table 10, APC value $=0.318$; ARS $=0.827$; and AARS $=0.821$ and all of these values are significant at the level $(<0.001)$. Thus, it can be concluded that the model in this study meets the criteria. This result is also supported by AVIF and AFVIF which are used as indicators to see whether or not multicollinearity occurs. The resulting value for AVIF is 1.952 and AFVIF is 2.404. This value is below 5 or under 3.3. it means that this research model has met the criteria and there are no multicollinearity problems between indicators and between exogenous variables and the GoF value of 0.752 is included in the large category $(0.752>0.36)$. It can be concluded that the goodness of fit criteria of the model in this study have been met.

The results confirmed the first hypothesis testing of the effect of human resource capacity on the value of local government financial reporting information. The results of testing the first hypothesis show the resulting coefficient value of 0.525 (positive 0.525 ) and the resulting p-value of $0.001(<0.01)$, significant at the level of $=5 \%$, with $t$ ratios of 6.557 values $t$ is greater than $t$ table (1.960). The results indicate that human resource capacity has a positive and significant effect on the value of local government financial reporting information, so it can be said that the first hypothesis can be accepted.

In testing the second hypothesis of the effect of the government's internal control system on the value of local government financial reporting information, the results of testing the second hypothesis showed that the resulting coefficient value is 0.339 (positive 0.339 ) and the resulting p-value is $0.001(<0.01)$, significant at the level of $=5 \%$, with the $t$ ratios value of $4.040 . t$ is greater than $t$ table (1.960). The results found that the government's internal control system has a positive and significant effect on the value of local government financial reporting information, so it can be said that the second hypothesis can be accepted.

Statistical output showed that in examining the third hypothesis of the effect of human resource capacity on the value of local government financial reporting information moderated by utilization of information technology, the results showed that the resulting coefficient value is 0.214 (positive 0.214) and the resulting p-value is $0.007(<0.01)$, significant at the level of $=5 \%$, with $\mathrm{t}$ ratios of 2,477 values. $t$ is greater than $t$ table (1.960), which means that there is a positive and significant influence. Based on these results, it shows that the use of information technology moderates the relationship between human resource capacity and the value of local government financial reporting information, so it can be said that the third hypothesis can be accepted.

Table 10. Fit Model Measurement

\begin{tabular}{|c|c|c|c|}
\hline Parameter & Value & Criteria & Information \\
\hline Average path coefficient (APC) & $0.318, \mathrm{P}<0.001$ & $\mathrm{p}<0.05$ & Model Fit \\
\hline Average R-squared (ARS) & $0.827, \mathrm{P}<0.001$ & $\mathrm{p}<0.05$ & Model Fit \\
\hline Average adjusted R-squared (AARS) & $0.821, \mathrm{P}<0.001$ & $\mathrm{p}<0.05$ & Model Fit \\
\hline Average block VIF (AVIF) & 1.952 & acceptable if $<=5$, ideally $<=3.3$ & Model Fit \\
\hline Average full collinearity VIF (AFVIF) & 2.404 & acceptable if $<=5$, ideally $<=3.3$ & Model Fit \\
\hline Tenenhaus GoF (GoF) & 0.752 & $\begin{array}{c}\text { small }>=0.1, \text { medium }>=0.25, \\
\text { large }>=0.36\end{array}$ & Model Fit \\
\hline
\end{tabular}


Lastly, in testing the fourth hypothesis on the effect of government internal control system on value of local government financial reporting information moderated by utilization of information technology, the results of testing the fourth hypothesis showed that the resulting coefficient value is 0.192 (positive 0.195 ) and the resulting $p$-value is $0.015(<0.01)$, significant at the level of $=5 \%$, with the $t$ ratios value of 2.210. $t$ is greater than $t$ table (1.960), which means that there is a positive and significant influence. The results indicate that the use of information technology moderates the relationship of the government's internal control system to the value of local government financial reporting information, so it can be said that the fourth hypothesis can be accepted [30] (Purnamasari et al., 2021). This is in line with previous studies highlighting the importance of information technology in auditing and financial reporting practices [16], [17], [18], [19], [20] (Hertati \& Zarkasyi, 2015; Sawitri et al., 2019; Xiao et al., 1996; Garg \& Divya 2009; Al-Hajaya \& Sawan, 2018).

\section{Conclusions}

The results showed that human resource capacity has a positive and significant impact on the financial reporting information in local government context. The results also showed that the internal control system has a positive and significant effect on financial reporting information. In examining the mediating effects, the results found that utilization of information technology moderates the relationship between human resource capacity and the financial reporting information, and also moderates the relationship between the internal control system and financial reporting information.

There are some limitations in this study. There are several indicators that the statement on the questionnaire is invalid, namely the cross-loading value of the government internal control system variable which causes the AVE value not meet the validity requirements so that the convergent validity test is carried out twice. As suggested this research is expected to provide additional knowledge and as a source of information in the development of public sector accounting science and contribute to research development. For further researches, it is recommended to use other variables that may affect the value of local government financial reporting information and use other factors as moderating variables. For government agencies, it is expected to be able to maintain and improve the quality of the value of their financial reporting information as a form of accountability by paying attention to and increasing human resource capacity by conducting trainings and developing information technology both at the system level and means of communication that are evenly available in all government units in Palu City.

\section{REFERENCES}

[1] Indra Bastian, "Akuntansi Sektor Publik Suatu Pengantar," Jakarta: Erlangga, 2010.

[2] Andi Chairil Furqan, Ratna Wardhani, Dwi Martani, Dyah Setyaningrum, "Financial reporting, public services and local executives' re-electability in Indonesia," Cogent Business \& Management, vol. 8, no. 1, pp. 1939229, 2021.

[3] Rahma Masdar, Andi Chairil Furqan, Masruddin Masruddin, Lucyani Meldawaty, "The role of transparency and professional assistance in regional financial management in the Indonesian regional governments," Journal of Public Affairs, vol. 21, no. 3, pp. e2666.

[4] Bambang Pamungkas, Cendy Avrian, Reisya Ibtida, "Factors influencing audit findings of the Indonesian district governments' financial statements," Cogent Business \& Management, vol. 6, no. 1, 1673102, 2019.

[5] Ade Anggraeni, "Executive role in the use of information technology in public organisations," Arthatama, vol. 4, no. 1, pp. 17-32, 2020.

[6] Muhammad Arshandi, "BPK Bilang Laporan Keuangan Sembilan Daerah Di Sulteng Bermasalah," Antaranews.com, 28 May 2019, retrieved from https://sulteng.antaranews.com/berita/63855/bpk-bilang-la poran-keuangan-sembilan-daerah-di-sulteng-bermasalah.

[7] Lesi Hertati, Wahyudin Zarkasyih, Harry Suharman, Haryono Umar, "The Effect of Human Resource Ethics on Financial Reporting Implications for Good Government Governance (Survey of Related Sub-units in State-owned Enterprises in SUMSEL)," International Journal of Economics and Financial Issues, vol. 9, no. 4, pp. 267-276, 2019.

[8] Nunuy Nur Afiah, Dien Noviany Rahmatika, "Factors influencing the quality of financial reporting and its implications on good government governance," International Journal of Business, Economics and Law, vol. 5, no. 1, pp. 111-121, 2014.

[9] Sudhir C. Das, "Corporate social reporting and human resource disclosures: experiences from insurance companies in India," Social Responsibility Journal, vol 9, no. 1, pp. 19-32, 2013.

[10] Krishanthi Vithana, Teerooven Soobaroyen, Collins G. Ntim, "Human resource disclosures in UK corporate annual reports: To what extent do these reflect organisational priorities towards labour?," Journal of Business Ethics, vol. 169 , no. 3, 475-497, 2021.

[11] Wahyu Setyawan, Rindu Rika Gamayuni, "The Quality of Financial Reporting and Internal Control System before and after the Implementation of E-budgeting in Indonesia Local Government," Asian Journal of Economics, Business and Accounting, vol. 14, no. 3, pp. 22-31, 2020.

[12] Nur Fitri Dewia, SM Ferdous Azama, Siti Khalidah Mohd Yusoff, "Factors influencing the information quality of local government financial statement and financial accountability," Management Science Letters, vol. 9, pp. 1373-1384, 2019.

[13] Nunuy Nur Afiah, Peny Cahaya Azwari, "The effect of the implementation of government internal control system 
(GICS) on the quality of financial reporting of the local government and its impact on the principles of good governance: A research in district, city, and provincial government in South Sumatera," Procedia-Social and Behavioral Sciences, vol. 211, pp. 811-818, 2015.

[14] Weili Ge, Zining Li, Qiliang Liu, Sarah McVay, "Internal control over financial reporting and resource extraction: Evidence from China," Contemporary Accounting Research, vol. 38, no. 2, pp. 1274-1309, 2021.

[15] Dain C. Donelson, Matthew S. Ege, John M. McInnis, "Internal control weaknesses and financial reporting fraud," Auditing: A Journal of Practice \& Theory, vol. 36, no. 3, pp. 45-69, 2017.

[16] Lesi Hertati, I. Zarkasyi, "Competence of human resources, the benefits of information technology on value of financial reporting in Indonesia," Research Journal of Finance and Accounting, vol. 6, no. 8, pp. 12-18, 2015.

[17] Ni Nyoman Sawitri, Dwi Ermayanti, Umi Farida, Dikson Junus, Ellys Rachman, Resista Vikaliana, "Human Resources Competency, The Use of Information Technology and Internal Accounting Control on Time Procurement of Financial Reporting," In Journal of Physics: Conference Series, vol. 1175, no. 1, p. 012263. IOP Publishing, 2019.

[18] Ze Zhong Xiao, John R. Dyson, Philip L. Powell, "The impact of information technology on corporate financial reporting: a contingency perspective," The British Accounting Review, vol. 28, no. 3, pp. 203-227, 1996.

[19] M. C. Garg, Divya Verma Gakhar, “Accounting Standard Disclosure Compliance in Online Reporting by Indian Companies," Asia Pacific Business Review, vol. 5, no. 2, pp. 141-153, 2009.

[20] Krayyem Al-Hajaya, Nedal Sawan, "The future of internet corporate reporting-creating the dynamics for change in emerging economies: A theoretical framework and model," Corporate Ownership and Control, vol. 15, no. 3, 172-188, 2018.

[21] Muhammad Natsir, Abdul Pattawe, Nurhayati Haris, Femilia Zahra, "The effects of work experience, ethical profession, and auditor independence on auditing performance of supervisory agency in central Sulawesi, Indonesia," Academy of Entrepreneurship Journal, vol. 27, no. 4, pp. 1-9, 2021.

[22] Muhammad Ikbal Abdullah, Andi Chairil Furqan, Nina
Yusnita Yamin, Fahri Eka Oktora, "Incentive Function of Audit Opinion for the Increase of Regional Operational Expenditure and Own-Source Revenues Through Sensitivity Analysis in Indonesia," Research in World Economy, vol. 11, no. 1, pp. 20-27, 2020.

[23] Dwi Asih Surjandari, Irma Martaningtyas, "An Empirical Study: The Effect of Performance Incentives, Internal Control System, Organizational Culture, on Fraud of Indonesia Government Officer," Mediterranean Journal of Social Sciences, vol. 6, no. 5 S5, pp. 71, 2015.

[24] Muhammad Din, Imam Ghozali, Tarmizi Achmad, "The Follow Up of Auditing Results, Accountability of Financial Reporting and Mediating Effect of Financial Loss Rate: An Empirical Study in Indonesian Local Governments," European Research Studies Journal, vol. 20, no. 4A, pp. 443-459, 2017.

[25] Mikhail A. Gorodilov, Alina V. Posohina, Tatiana V. Pashchenko, Aleksandr S. Belyaev, "Procurements: Government Regulation to Reduce the Risk of Fraud in the Context of Information Technology Development," In International Perm Forum Science and Global Challenges of the 21st Century, pp. 993-1005. Springer, Cham, 2021.

[26] Muhammad Fakhimuddin, Uswatun Khasanah, Rini Trimiyati, "Database Management System in Accounting: Assessing the Role of Internet Service Communication of Accounting System Information," Research Horizon, vol. 1, no. 3, pp. 100-105, 2021.

[27] Lexis Alexander Tetteh, Amoako Kwarteng, Felix Kwame Aveh, Samuel Ato Dadzie, Disraeli Asante-Darko, "The Impact of Internal Control Systems on Corporate Performance among Listed Firms in Ghana: The Moderating Role of Information Technology," Journal of African Business, ahead-of-print, 2020.

[28] Yunhao Chen, Antoinette L. Smith, Jian Cao, Weidong Xia, "Information technology capability, internal control effectiveness, and audit fees and delays," Journal of Information Systems, vol. 28, no. 2, pp. 149-180, 2014

[29] Andi Mattulada Amir, Ridwan Ridwan, Muhammad Din, Nina Yusnita Yamin, Femilia Zahra, Muh. Fiqram Firman, "The Role of Budget Participation in Improving Managerial Performance," Accounting, vol. 7, no. 2, pp. 269-280, 2021.

[30] Dewi Purnamasari, Ayu Almira, Nadia Della Savira, "The Accounting for Inventory from a Commercial Point of View," Research Horizon, vol. 1, no. 2, pp. 81-85, 2021. 